\title{
Powering primary healthcare centres with clean energy sources
}

\author{
Vincent Anayochukwu Ani* \\ Braun School of Public Health and Community Medicine, Hebrew University of Jerusalem - Hadassah Ein Kerem, P.O. Box \\ 12272, Jerusalem 91120, Israel
}

Received: 19 April 2020 / Received in final form: 10 December 2020 / Accepted: 11 December 2020

\begin{abstract}
Primary Healthcare Centres (PHCs) remain the populations' first point of contact when seeking medical help. Women and children, whose health status decides the fate of the country, are the predominant users of primary healthcare centres which means they (the PHCs') must function as high quality health providers. Karshi Primary Healthcare Centre (KPHC) is one of the health facility that need reliable electricity to improve their healthcare delivery. Due to unreliable power supply, they rely on a diesel powered solution as a primary source of power supply. This negatively impacts patients and the environment, and has been a burden on their operational budgets. Change in energy system is the solution to this unreliable, costly, and unsecure power supply in Karshi, and its objective is to improve and enhance the quality of healthcare delivery services. The assumption is that with better energy source, there will be better healthcare services. A solar powered system with battery storage was proposed as the solution and the simulation results demonstrate that except for the initial cost of investment, the solar PV generator performs better than the diesel generator, in terms of the life cycle costs and the cost per unit energy. The life cycle cost and the cost of energy show a decrease of $75 \%$ each. The environmental analysis implies that the solar PV energy system has the potential to avoid the $9371 \mathrm{~kg}$ of carbon dioxide if the system is implemented in the future at KPHC. The proposed powered system will supply electricity for the laboratory equipment (centrifuges, microscopes, blood chemical analyzer, hematology analyzer, CD4 machine), vaccine-refrigeration, general purpose refrigerator, computer and telecommunications, while being able to cater to a greater number of patients than in the past.
\end{abstract}

\section{Introduction}

Operators of health facilities in developing nations across the world are faced with problem of unreliable power supply which has hindered its functionality, thus, limiting the effective delivery of quality healthcare services to the populace particularly by the main users of services (mothers and children) [1]. Maternal health is a crucial indicator of quality of health care in any country. By definition, maternal health refers to the health of women during pregnancy, child birth and postpartum periods. The health of a woman is tied to the health and wellbeing of her children, her family and community as a whole [2]. Thus, when there is maternal mortality, it reflects one of the shameful failures of human development in a country [3]. Nigeria as one of the developing nations is the largest country in Africa, it has a population of about 180 million [4] and it is still growing. The maternal mortality ratio in health facilities across Nigeria is disturbingly high, with

\footnotetext{
* e-mail: anayochukwu.vincent@gmail.com
}

313 women dying from complications of pregnancy and childbirth for every 100000 live births [5]. Newborn outcomes are particularly alarming, with 58 newborns dying in the first few hours of life per every 1000 born in health facility [5]. According to Karshi Primary Healthcare Centres' (KPHC) annual maternity performance report (as the Tab. 1 shows), there are 39.9 newborns dying in the first few hours of live births per every 1000 born in the health facility as compared to national average of 37 per 1000 live births (as shown in Tab. 2) [6]. The large scale corruption, caused by the poverty in the country also affects energy supply in Nigeria. Power supply is a major impediment to the management of primary healthcare facilities. Between 2013 and 2016, Nigeria generated between 3000 and $4500 \mathrm{MW}$ (megawatts) of electricity, far less than the estimated demand of 10 000-12 $000 \mathrm{MW}$ [7]. This has resulted in frequent and unpredictable load shedding which has affected many communities' healthcare centres, forcing them to rely on kerosene lantern as source of lighting and diesel generators as their primary source of electricity. The Karshi Community in Abuja Municipal Area Council 
(AMAC) of Federal Capital Territory $(\mathrm{FCT})^{1}[8]$ is among the many communities affected by the country energy crisis. Karshi healthcare centre has been experiencing worsening power outages in the past several years, with power outages lasting from several hours to several days. Many of the functions in this healthcare facility depend on a reliable supply of electricity for critical care situations, and the loss of power can easily contribute to loss of life. Due to the unreliable power supply, the facility now relies on a diesel powered solution. The power situation is so unreliable that the generator runs on morning and afternoon and that consumes a lot of diesel, and negatively impacts patients and the environment. This is where energy intervention (change in energy system) is needed, and will be demonstrated here as outlined by the author's recent research work [9]. Using generators to cope with the irregular power supply is therefore a burden on the operational budgets of the health facility. When prices go up for diesel, the budget doesn't increase, and existing or planned public health programs have to be reduced or delayed because less money was available from the budget. Therefore, better energy generation and management is one of the keys to improving public health, and one of the ways to control increasing cost in this public health setting is to reduce the energy cost by moving to a different system of energy. The theory of change here is that reliable energy provision to the health centre will lead to better health outcomes in the population based on the fact that the quality of health services provided can be improved with access to electricity.

\subsection{Justification for installing solar powered system in the healthcare facility}

Based on literature, installation of solar powered system for the community healthcare centre will drastically reduce the facility energy costs and this in turn will increase the quality of healthcare delivery in Karshi-Abuja. For instance, in Tanzania, a health facility (Kilimatinde hospital) in the Singida Region used to spend up to 120 litres of diesel a month to run the hospital generator during times of emergency, at a cost of about Tsh 240000 per month (approximately 118.00€). After the installation of the solar electricity in 2011 by the United States Agency for International Development (USAID), all idle laboratory equipment before became fully functional, and the

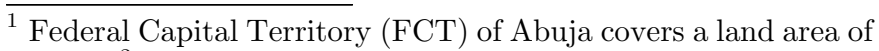
$8000 \mathrm{~km}^{2}$ and is located in the middle of the country. Abuja falls within latitude $7^{\circ} 25^{\prime} \mathrm{N}$ and $9^{\circ} 20^{\circ}$ North of the Equator and longitude $5^{\circ} 45^{\prime}$ and $7^{\circ} 39^{\prime}$ East of Greenwich. The FCT is subdivided into six Area Councils - Abaji, Abuja Municipal, Bwari, Gwagwalada, Kuje and Kwali. The urban areas are in the Federal Capital City (FCC) namely, Garki, Maitama, Wuse, Asokoro, Gwarinpa and Gudu districts. Other urban areas are the Local Government or Area Council headquarters. Notable suburban districts popularly called satellite towns include Kubwa, Nyanya, Karu, Karshi, Karmo, Lugbe and Idu. Others are Gwagwa, Jiwa and Jikwoyi in the Municipal Area Council. Some remote villages, Kuchigoro and Aleyita, near the city, in Abuja Municipal Area Council, are beginning to grow.
}

facilities have immensely reduced their operating costs (in terms of fuel and maintenance) while also being able to cater to a greater number of patients than in the past [10].

Also, in Tanzania, a health facility (Talawanda clinic) in the Bagamoyo district serves six villages equaling a population of 10 791; Talawanda averages 20-35 patients during the day, 7-10 at night, 18 deliveries per month. With seven clinical rooms, Talawanda Clinic's doctors had a difficult time dealing with patients at night without electricity and sometimes the lack of electricity could have caused the doctors to misdiagnose or make mistakes when treating patients. Innovation Africa installed solar energy in 2013 at Talawanda Clinic providing 10791 people with more opportunities toward a healthy future [11]. This program has seen success.

In Rwanda, the Solar Electric Light Fund (SELF) in collaboration with Partners in Health (PIH) (two nonprofit healthcare organizations) equipped five health clinics for the communities of Mulindi, Rusumo, Rukira, Nyarabuye, and Kirehe with $3.4-4.3 \mathrm{~kW}$ solar photovoltaic systems. These clinics provide healthcare services to approximately 400000 people. The systems supply electricity for laboratory equipment (microscopes, blood analysis machines, centrifuges, portable $\mathrm{X}$-ray machines and sterilization devices). They also supply electricity for vaccine refrigeration, telecommunications and computers (patient records, etc.) [12].

In Zambia, the United Nations Development Programme (UNDP) with Norwegian Emergency Preparedness System (NOREPS) installed a solar power systems in three primary healthcare clinics in Mpepo, Mulekatembo and Kazembe in Eastern Province. The idea was to test whether those could provide valid alternatives to classical power systems or fuel-based generators. The pilot project was a success and proved that solar power generation systems can be an effective and cost-efficient climate change mitigation alternative [13].

According to the World Bank's report on solar mapping resources in Zambia [14], the average annual global horizontal irradiation (GHI) for the country varies between 5.5 and $6.3 \mathrm{kWh} / \mathrm{m}^{2}$ day, whereas in Nigeria, the average annual GHI varies between 3.5 and $7.0 \mathrm{kWh} / \mathrm{m}^{2} /$ day [15]. Since the pilot project was successful in Zambia and comparing the global horizontal irradiation of Nigeria with that of Germany $\left(2.7-3.3 \mathrm{kWh} / \mathrm{m}^{2} /\right.$ day) [16], the country with the most installed PV systems in the world, Nigeria's high PV power generation potential could be better harnessed to power health facilities.

\subsection{Significance and novelty of the study}

The significance of the study is based on comparative case studies and success in similar settings in which solar system has been used as a replacement and had positive outcomes. The novelty of the study is that it has not been done before in Karshi, and it is similar enough to be able to take the success from these low-middle income countries (Tanzania, Rwanda, and Zambia), and replicate it in Karshi. This novel is not for low-income countries, it is novel for Nigeria. In these three similar settings, these projects has been run effective to reduce the operational costs for their energy 


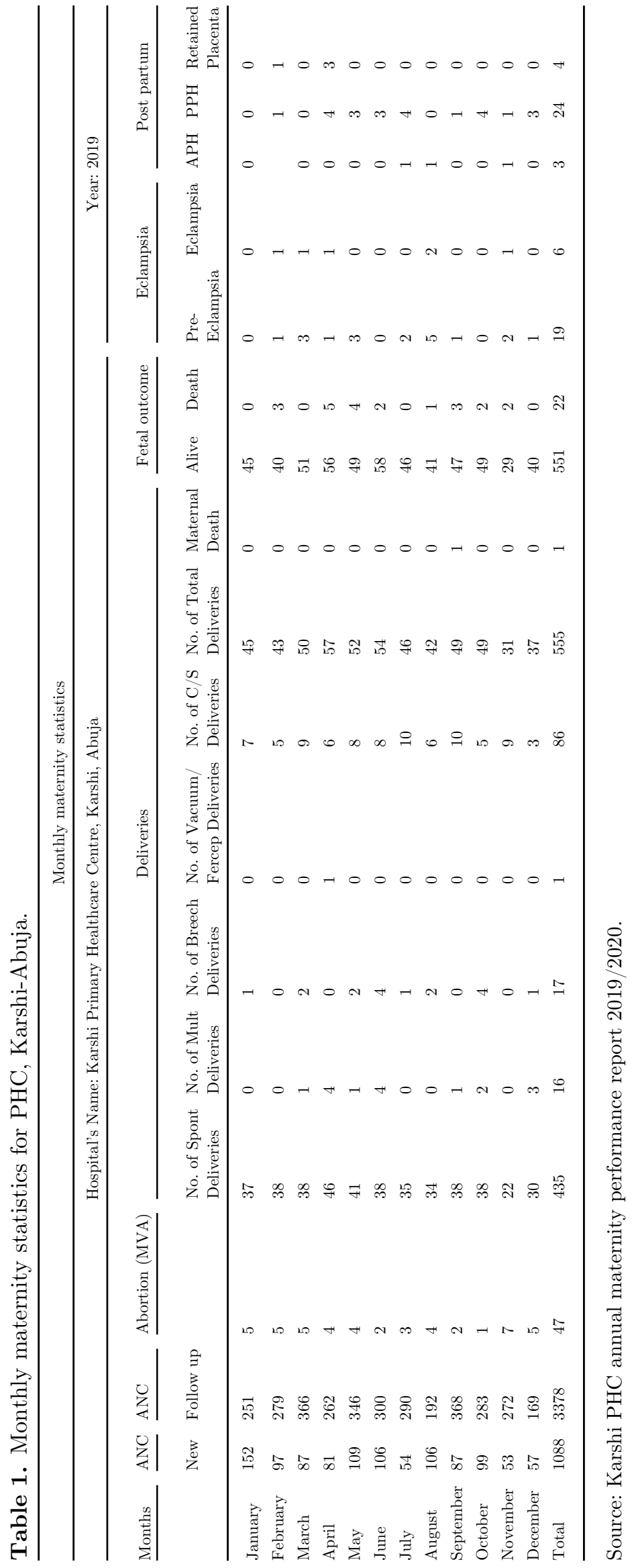


Table 2. Comparative neonatal mortality rate per 1000 live births by region [6].

\begin{tabular}{ll}
\hline Region & Deaths per 1000 live births \\
\hline South-South & 32 \\
North-Central & 35 \\
South-East & 37 \\
South-West & 39 \\
North-East & 43 \\
North-West & 44 \\
National average & $\mathbf{3 7}$ \\
\hline
\end{tabular}

supply, increase quality of healthcare delivery services, and increase access to health services. It was proposed based on the success of these and the need of the Karshi that a pilot will be run in Karshi with hopefully be effective and then will be able to scale up to the rest of Nigeria. The assumption is that with more reliable, secure and costeffective energy source, the health workers will be able to do their work better.

\section{Description of the program site - Karshi in Abuja (FCT)}

Karshi community is located in Abuja Municipal Area Council, and is one of the satellite towns of Abuja, Nigeria's capital city [17]. The precise boundaries and population of Karshi are difficult to determine, given that it consists of at least two main settlement areas that spill over from Abuja into Nasarawa. Karshi in itself is divided into two; we have the Karshi-Abuja and Karshi-Nasarawa [18]. The two Karshi is separated by a road known as bypass. The Abuja-Karshi is on the right of the bypass while the Nasarawa-Karshi is on the left when approaching from Karu-Jikwoyi-Kurudu-Orozo express road. It should be noted that henceforth "Karshi" in this paper refers to the Karshi-Abuja as opposed to Karshi-Nasarawa.

\subsection{Demography}

Despite the lack of up-to-date statistics, Karshi is known to be one of the fastest growing satellite towns in Abuja. The growth and development of Karshi as a satellite town of Abuja is to a large degree dependent upon the growth of Nigeria's Federal Capital Territory. At the 2006 census, the city of Abuja had a population of 776 298, making it one of the ten most populous cities in Nigeria. In 2008, the FCT has an estimated population of about 1.4 million with AMAC having a population of about $780 \quad 000$ [19]. Therefore the current population of the Karshi is likely to be far higher than the last census count of 15084 [20].

\subsection{Health and healthcare services in karshi}

A primary healthcare service centre should at least have the following in terms of infrastructure: the building in which it is housed be in good condition; basic drugs \& vaccines and equipment such as a refrigerator, sterilizers etc; availability of electricity and running water; the presence of a telephone or some means of communication for situations where ambulatory and emergency care may be required [18]. Investigation into infrastructure aspect reveals that the operations of equipment like communication system, running water, heating and refrigerating systems are based on availability of a robust and uninterrupted power supply. In terms of infrastructure, the quality of healthcare services provided may be assessed by an adequately equipped and easily accessible public health facility, and uninterrupted power supply is required to make these equipment functional. Primary healthcare centre in Karshi community is located in Abuja Municipal Area Council, one of 6 area councils in the Federal Capital Territory [8]. Karshi primary healthcare runs preventive, curative and the following services;

- Immunization

- Ante-natal care

- Delivery

- Family planning

- Laboratory diagnosis and treatment

\section{Challenges of the healthcare services}

Karshi primary healthcare services was beset with a number of challenges. One of the major challenges of healthcare services in Karshi was that of epileptic power supply. Another major challenge of healthcare services was due to population explosion which overstretched the facility. The majority of this population were informal community dwellers (squatters) which constituted about 50 percent of the users of health services in Karshi. These people were not taken into account when the primary healthcare centre was built. The problem was compounded because people from neighbouring communities preferred to patronise Karshi primary healthcare centre because of the relatively cheaper cost. As a consequence, there was general overstretch of the healthcare facility. Other challenges faced by healthcare delivery included lack of adequate number of health personnel and depreciation of work tools.

\section{Environmental problems}

One major environmental problem in Karshi is that of pollution. The satellite town is harmed by air pollution that comes predominantly from electricity generators (diesel genset power systems), and also emits frustrating noise pollution, which presents real health risks to Karshi's residents.

\subsection{Electricity needs assessment}

The energy needs assessment was carried out in Karshi primary healthcare centre to assess the electrification status of the health facility and its state of energy access through a series of key informant interviews at the PHC. 
Table 3. Load Profile for the PHC facility.

\begin{tabular}{|c|c|c|c|c|c|c|c|c|c|}
\hline $\mathrm{S} / \mathrm{no}$ & Power consumption & Qty & $\begin{array}{l}\text { Power } \\
\text { (Watts) }\end{array}$ & $\begin{array}{l}\text { Total } \\
\text { (Watts) }\end{array}$ & $\begin{array}{l}\text { Daytime hours } \\
(07.00-17.59)\end{array}$ & $\begin{array}{l}\text { Evening hours } \\
(18.00-21.59)\end{array}$ & $\begin{array}{l}\text { Night hours } \\
(22.00-06.59)\end{array}$ & $\begin{array}{l}\text { Total Hours/ } \\
\text { day }\end{array}$ & $\begin{array}{l}\text { Total Energy } \\
(\mathrm{kWh} / \text { day })\end{array}$ \\
\hline \multicolumn{10}{|c|}{ Clinical medical devices } \\
\hline 2 & Centrifuge & 2 & 242 & 484 & 4 & & & 4 & 1.94 \\
\hline 3 & Microscope & 2 & 20 & 40 & 6 & & & 6 & 0.24 \\
\hline 6 & CD4 Machine & 1 & 200 & 200 & 4 & & & 4 & 0.80 \\
\hline \multicolumn{10}{|c|}{ Lighting } \\
\hline 7 & Interior Lighting (a) & 2 & 60 & 120 & 11 & 4 & 9 & 24 & 2.88 \\
\hline 8 & Interior Lighting (b) & 3 & 60 & 180 & 10 & 4 & & 14 & 2.52 \\
\hline 9 & Security Lighting & 2 & 60 & 120 & & 4 & 9 & 13 & 1.56 \\
\hline 11 & Radio & 1 & 30 & 30 & 2 & & & 2 & 0.06 \\
\hline 12 & Desktop Computer & 1 & 230 & 230 & 4 & & & 4 & 0.92 \\
\hline 13 & Fan & 5 & 75 & 375 & 8 & 5 & & 13 & 4.88 \\
\hline
\end{tabular}

Source: Data from the service providers, key informant interview.

Service providers' (which include nurses, CHWs (community health workers) and laboratory personnel) were interviewed using a structured questionnaire (see the Appendix), which produced Table 3. This was followed by an analysis of the energy audit data and site-specific recommendations for improved energy solution.

\section{The PHC facility load profile}

In this facility, electricity is required for:

- lighting during evening hour's operations and lighting of surroundings.

- Powering refrigerator-vaccine for keeping cold chain vaccines, blood bank; and general purpose refrigerator for keeping other medical supplies at required temperature.

- Powering basic laboratory equipment including; centrifuge, microscope, blood chemical analyzer, hematology analyzer, CD4 Machine. Other appliances that require electrical power includes; radio, desktop computer, and fans.

However, these loads are not expected to operate simultaneously, because each has specific daily hours of operation as shown in Table 3. Table 6 shows the hourly load profile of the PHC, where average energy consumption per day and the peak demand is found to be approximately $10.03 \mathrm{kWh}$ and $1.29 \mathrm{~kW}$ respectively. Major load occurs during the daytime ( $7 \mathrm{am}-6 \mathrm{pm})$.

\section{Selection of energy system}

In order to reduce the energy costs and energy-related $\left(\mathrm{CO}_{2}\right)$ emissions, renewable energy system is needed. The renewable energy situation assessed through field survey and experiments [15] confirmed that solar energy is available in abundant quantity, more or less equally distributed over the country throughout the year. Wind energy source or hydro power plants are much more site specific, suitable for fewer locations and unevenly distributed during the year. Biomass resources are insufficient to generate and distribute electricity on a sustainable basis. Out of all the renewable energy sources, however, the solar photovoltaic (solar PV) ${ }^{2}[21]$ solutions are the most suitable for the primary healthcare centres in Nigeria.

\subsection{Energy efficiency (EE) model}

Once the energy needs of a healthcare facility have been identified, the next task is selecting and implementing the most appropriate and effective energy efficiency measures to minimize these needs. "Energy efficiency" refers to policies, strategies and technologies designed to reduce energy consumption, carbon emissions and costs [22]. Energy efficiency measures for existing healthcare facilities can be simple actions such as controlling the opening and closing of windows and switching off non-essential devices when not in use. One example is maximizing access to

\footnotetext{
${ }^{2}$ Solar photovoltaic (PV) generators convert the energy from the sun into electricity through their solar cells, which are semiconductor-based materials. These solar cells are gathered together to form a solar panel. Each panel can have a peak capacity from 80 to $200 \mathrm{~W}$, depending on size and technology. Panels can be installed together in order to achieve the desired output capacity. The amount of solar energy received at a specific location is called insolation, and this factor determines the output of the PV generator. Solar resources are universally available at any location with higher values closer to the Equator.
} 
Table 4. Savings through the use of more efficient appliances in the health facility.

\begin{tabular}{lll}
\hline Energy/Cost savings & $\mathrm{kWh} /$ year & Cost/year \\
\hline $\begin{array}{l}\text { Forecast load demand - medical devices and health } \\
\text { services basic amenities (conventional) powered by Diesel }\end{array}$ & 6935 & $8779.00 €$ \\
$\begin{array}{l}\text { system (Tab. 3) } \\
\text { New load demand Forecasted - medical devices and health }\end{array}$ & 3632 & \\
\hline
\end{tabular}
services basic amenities (energy-efficient) powered by Solar system (Tab. 5)

Reduction in use and cost

$3303(-31.3 \%)$

$6672.00 €(-61.3 \%)$

Table 5. Load profile for the PHC facility to be powered by the solar system.

\begin{tabular}{|c|c|c|c|c|c|c|c|c|c|}
\hline $\mathrm{S} / \mathrm{no}$ & Power consumption & Qty & $\begin{array}{l}\text { Power } \\
\text { (Watts) }\end{array}$ & $\begin{array}{l}\text { Total } \\
\text { (Watts) }\end{array}$ & $\begin{array}{l}\text { Daytime hours } \\
(07.00-17.59)\end{array}$ & $\begin{array}{l}\text { Evening hours } \\
(18.00-21.59)\end{array}$ & $\begin{array}{l}\text { Night hours } \\
(22.00-06.59)\end{array}$ & $\begin{array}{l}\text { Total } \\
\text { hours/day }\end{array}$ & $\begin{array}{l}\text { Total energy } \\
(\mathrm{kWh} / \text { day })\end{array}$ \\
\hline \multicolumn{10}{|c|}{ Clinical medical devices } \\
\hline 2 & Centrifuge & 2 & 242 & 484 & 4 & & & 4 & 1.94 \\
\hline 3 & Microscope & 2 & 20 & 40 & 6 & & & 6 & 0.24 \\
\hline 6 & CD4 Machine & 1 & 200 & 200 & 4 & & & 4 & 0.80 \\
\hline \multicolumn{10}{|c|}{ Lighting } \\
\hline 7 & Interior Lighting (a) & 2 & 12 & 24 & 11 & 4 & 9 & 24 & 0.58 \\
\hline 8 & Interior Lighting (b) & 3 & 12 & 36 & 1 & 4 & & 5 & 0.18 \\
\hline 9 & Security/Pathway Lighting & 5 & 18 & 90 & & 4 & 9 & 13 & 1.17 \\
\hline 12 & Phone charge & 2 & 7.5 & 15 & 2 & & & 2 & 0.03 \\
\hline 13 & Notebook Computer & 1 & 30 & 30 & 4 & & & 4 & 0.12 \\
\hline 14 & Fan & 5 & 25 & 125 & 8 & 5 & & 13 & 0.38 \\
\hline 15 & Miscellaneous equipment & 1 & 100 & 100 & 7 & & & 7 & 0.70 \\
\hline
\end{tabular}

natural ventilation and daylight [23] to improve energy performance, which is a great potential for energy efficiency in healthcare facilities. Energy efficiency is a crucial component for the demand side management (energy consumption), the dimensioning of the solar photovoltaic system (in order to prevent the generating system from being over burdened) and as a consequence, the investment cost and financial viability. In this project, the health facility's 2020+ energy needs was forecasted to be approximately $6935 \mathrm{kWh} / \mathrm{yr}$. costing $8779.00 €$ annually (about 3710105 ) - although the facility is underfunded; its annual budget on electricity, fuel and other maintenance is 360000.00 (about $864.00 €$ ). For this design, an energy-efficient health services for basic amenities is applied through the replacement of lighting and window system in order to reduce energy use and cost. The healthcare centre has over 5 rooms, all with very outdated lighting. A lighting audit has been performed, and the types and locations of replacement bulbs (using LED lighting) have been identified. The annual savings will be substantial, reducing the lighting $\mathrm{kWh}$ used by over $72 \%$ and costs by at least $1680.00 €$ every year compared to what the usage would be without a replacement lighting effort. Also, replacement of wooden windows with glass windows will illuminate the rooms by allowing rays of light in thereby reducing hour of lighting use (as from 8.00 to $17.00 \mathrm{~h}$ ), and this will further save about $285 \mathrm{kWh} /$ year. Table 4 illustrates the expected savings. This effort will reduce costs by AT LEAST $6672.00 €$ every year beginning in 2020. This is significant and a true example of energy/ cost savings that will be showcased to the healthcare policy makers.

After the energy efficiency model which resulted in the generation of Tables 5 and 6 from Table 3 , we identified the solar resources of the location using a geographic information system (GIS) mapping as shown in Figure 1, then calculate the PV system sizing, and compare the costs and emissions of stand-alone power supply options (generator versus solar system) using HOMER. The simulation results are shown in Table 7. 


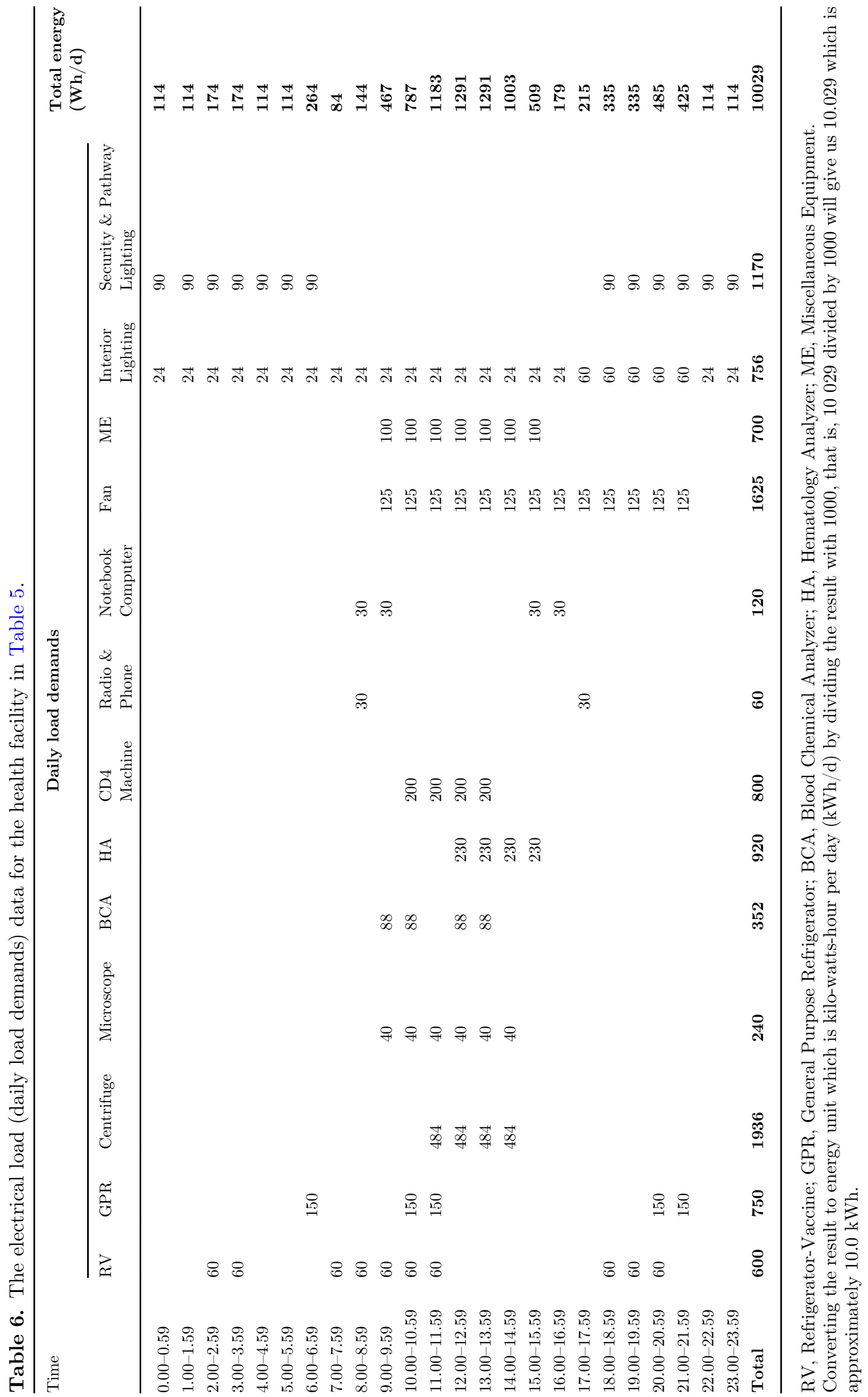




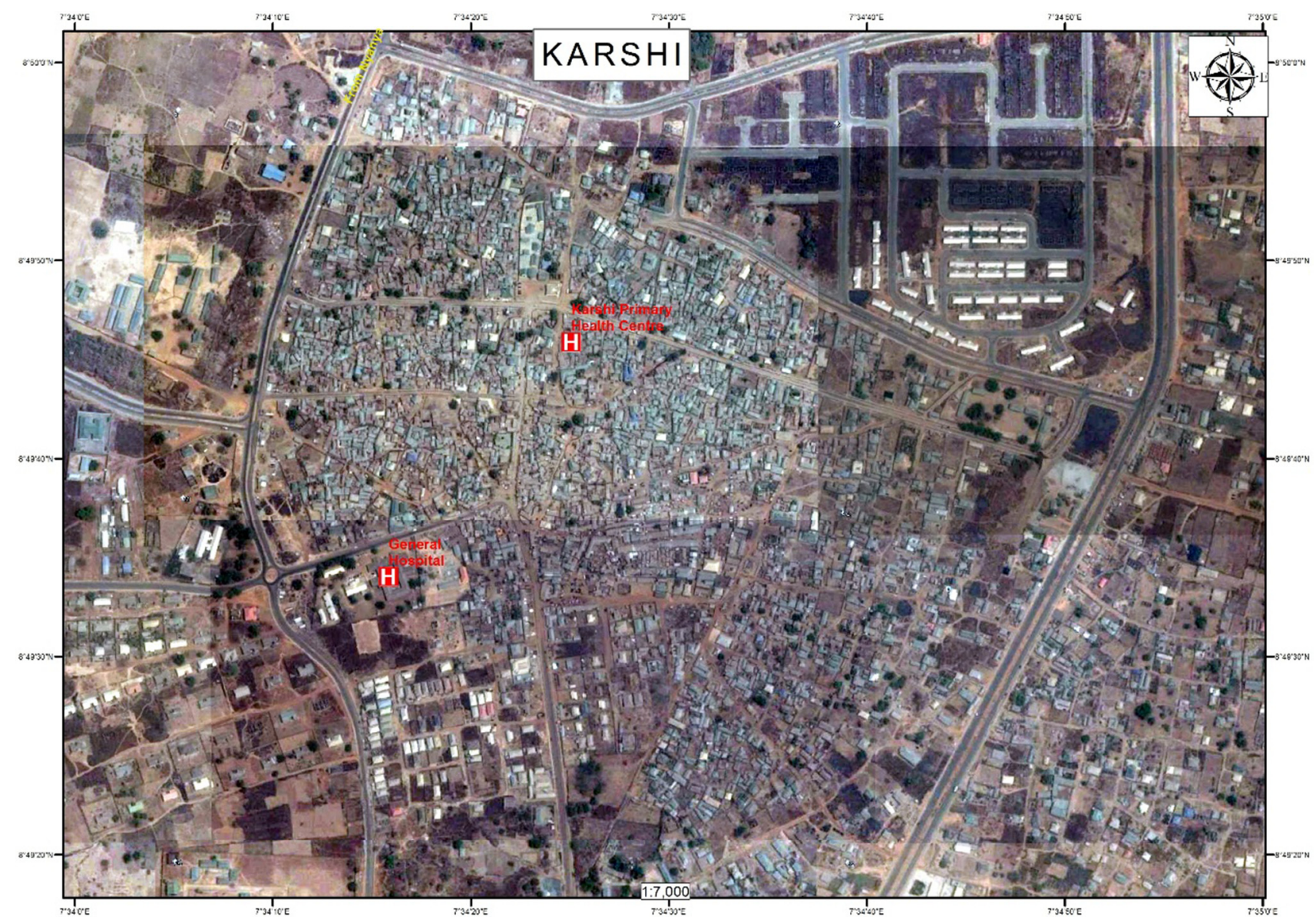

Fig. 1. GIS mapping showing the location of Karshi Primary Healthcare Centre.

Table 7. Comparative costs and emissions of stand-alone power supply options (generator versus solar system).

\begin{tabular}{lllllllllll}
\hline Configuration & $\begin{array}{l}\mathrm{PV} \\
\text { capacity } \\
(\mathrm{kW})\end{array}$ & $\begin{array}{l}\text { Generator } \\
\text { capacity } \\
(\mathrm{kW})\end{array}$ & $\begin{array}{l}\text { Number of } \\
\text { batteries } \\
(6 \mathrm{~V} / 225 \mathrm{Ah})\end{array}$ & $\begin{array}{l}\text { Converter } \\
\text { capacity } \\
(\mathrm{kW})\end{array}$ & $\begin{array}{l}\text { Initial } \\
\text { capital } \\
(€)\end{array}$ & $\begin{array}{l}\text { Annual } \\
\text { generator } \\
\text { usage }(\mathrm{h})\end{array}$ & $\begin{array}{l}\text { Annual } \\
\text { quantity } \\
\text { of diesel }(\mathrm{L})\end{array}$ & $\begin{array}{l}\text { Total net } \\
\text { present cost } \\
(€) \\
\text { for } 25 \mathrm{yr}\end{array}$ & $\begin{array}{l}\text { Cost of } \\
\text { energy } \\
(€ / \mathrm{kWh})\end{array}$ & $\begin{array}{l}\text { Renewable } \\
\text { fraction }\end{array}$ \\
\hline Generator only & 0 & 2.5 & 0 & 0 & 2100 & 8760 & 3558 & 85528 & $\begin{array}{l}\mathrm{CO}_{2} \\
\text { emission } \\
(\mathrm{t} / \mathrm{yr})\end{array}$ \\
$\mathrm{PV}+$ Battery & 10 & 0 & 10 & 2 & 19379 & 0 & 0 & 21478 & 0.58 & 0.00 \\
\hline
\end{tabular}

*The increase in diesel cost, opportunity cost of procurement of diesel in the area, down time of diesel generator (DG) sets for maintenance and repair, and benefits carbon credit accruing to solar PV plants are not factored in the calculation.

\section{Simulation results}

The simulation was done with the support of the Hybrid Optimization Model for Electrical Renewables (HOMER) developed by the US National Renewable Energy Laboratory (NREL). This tool is widely used and constitutes one of the main instruments in solar electrification planning. The load profile and the natural conditions are site specific, which means that the results are only valid for this site and should not be extrapolated to other PHCs. The simulation results are shown above (Tab. 7).

\section{Discussion}

A solar powered system with battery was proposed and the simulation results show that although diesel genset power system has a very low initial capital investment (2 100€) in comparison with solar photovoltaics (19 379€), the fuel costs of diesel, the running costs, and the replacement cost of the genset every 5 year due to wear and tear offset the low initial investments. Consequently, the genset's total net present cost (85 528€) are much higher when compared to solar photovoltaic $(21478 €)$ due to the high operation \& 
maintenance, and fuel costs. Therefore, the suitability of a solar PV system with battery in this primary healthcare centre was determined from the perspective of economical analysis.

Environmental impacts also was taken into consideration. Gensets are noisy and polluting, and have a direct health impact on patients and the environment. The diesel genset power system operates for $8760 \mathrm{~h}$ per annum, has a fuel consumption of $3558 \mathrm{~L}$ per annum, and emits 9.371 tonnes of $\mathrm{CO}_{2}$ emission annually into the atmosphere of the location of the primary healthcare centre as shown in Table 7. In contrast, the solar PV system operates without fuel consumption and generates no tonnes of $\mathrm{CO}_{2}$ emission. From the environmental analysis on pollutant emission, the solar PV system is preferred over diesel generators. If the diesel-only generator system is continued to be used by the Karshi primary healthcare centre, the $\mathrm{CO}_{2}$ generated based on the simulation results will possibly contribute to global warming in the near future.

Generally, installing a solar system at this particular facility has several advantages for the primary healthcare centre. First of all, the healthcare centre receives a new energy system that will help the management save money on maintenance of the generators and the fuel. Not only will the healthcare centre benefit from the project (reduced operational costs for energy supply), it will also have a large impact on the community it represents (reduced environmental impacts).

\section{Expected results}

By achieving the objective of this project, it will result in multiple benefits for the primary healthcare centre. These will include:

- increased access to health services as the health centre is able to provide consistent services;

- increased quality of healthcare as the health centre will be able to make use of the full range of diagnostic and emergency health services available;

- increased number of patients that can be attended to per day as improved lighting allows the health centre to stay open longer;

- reduced operational costs for health facilities' energy supply; and

- reducing environmental impacts through the use of solar powered system rather than fossil fuels.

\section{Conclusion}

The economic analysis of solar PV stand-alone system carried out in this investigation verifies the predictions for the brilliant future of solar PV energy technology for primary healthcare centres in Nigeria. The results demonstrate that except for the initial cost of investment, the solar PV generator performs better than the diesel generator, in terms of the life cycle costs and the cost per unit energy. The life cycle cost and the cost of energy show a decrease of $75 \%$ each. The solar PV system also has an advantage of being eco-friendly as compared to the diesel generation. The environmental analysis presented in this study implies that the solar PV energy system has the potential to avoid the $9371 \mathrm{~kg}$ of carbon dioxide if the system is implemented in the future at Karshi primary healthcare centre. Based on the load profile of the PHC facility and the simulation results, installation of solar powered system for the primary healthcare centre will drastically reduce the facility energy costs and this in turn will increase the quality of healthcare delivery in KarshiAbuja. This change in energy system will improve health service delivery, expand healthcare services and diagnostic services. The assumption is that the proposed energy provision to the health centre will lead to better health outcomes in the population based on the fact that the quality of health services provided can be improved with access to electricity. It is concluded that, the solar PV system with battery has a high potential for use in power generation at primary healthcare centres in Nigeria.

\section{Acknowledgments}

The author of this paper is grateful to Braun School of Public Health and Community Medicine, Hebrew University of Jerusalem - Hadassah Medical Organization and Pears foundation for awarding him a full scholarship that covers the costs of studying and living in Israel for the 2016/2017 International Master of Public Health (IMPH) programme. His sincere gratitude goes to Mrs. Elaine Ruth Fletcher and her family for their encouragement, support, caring and love during his stay in Israel. Additional sincere thanks to Mrs. Grace Ifunanya Anayochukwu, for pre-editing the article prior to its submission and publication.

\section{References}

1. L. Olatomiwa, Optimal configuration assessments of hybrid renewable power supply for rural healthcare facilities, Energy Rep. 2, 141-146 (2016)

2. M.A. Akanbi, D. Azuh, P.O. Adekola, A. Olawole-Isaac, C.J. Ejiegbu, Socio-economic factors influencing the utilization of maternal health care services in Amuwo-Odofin local government area of Lagos State, Nigeria, Int. J. Humanit. Arts Med. Sci. 3, 7-16 (2015)

3. L. Freedman, M. Wirth, R. Waldman, M. Chowdhury, A. Rosanfield, Background paper on the taskforce on child health and Maternal Millenium project commissioned by the UN secretary general and supported by the UN development group, 2003. http://www.unmillenniumproject.org/docu ment/tf04apr18.pdf (accessed November 24, 2020)

4. World Bank: The Little Data Book on Africa http:// siteresources.worldbank.org/INTSTATINAFR/Resources/ LDB-Africa-12-2-08.pdf (accessed June 6, 2020)

5. Saving Mothers, Giving Life (SMGL) Annual Report, Reducing Maternal Mortality in Sub-Saharan Africa, 2016. https://www.savingmothersgivinglife.org/docs/

SMGL_2016_Annual_Report.pdf (accessed June 15, 2020)

6. MamaYe, Infographics on Maternal, Newborn and Child Health in Nigeria. London: Evidence for Action-MamaYe. 2017. http://www.mamaye.org/resources/infographics/mamayeinfographics-maternal-newborn-and-child-health-nigeria (accessed November 10, 2020) 
7. 2013-2017 - Nigeria - Country Strategy Paper - African Development Bank Group. https://www.afdb.org/en/docu ments/document/2013-2017-nigeria-country-strategy-paper31073/ (accessed June 15, 2020)

8. E.O. Alaye-Ogan, Rural poverty among women in Nigeria: a case study of Abuja Satellite Communities of Nigeria, $\mathrm{PhD}$ Dissertation, Department of Development Economics, StClements University, Turks \& Caicos Islands, British West Indies, 2008

9. V.A. Ani, Provision of Reliable Electricity to Primary Health Care Facilities in Nigeria - A New Focus of Interventions, International Journal of Energy for a Clean Environment 22, 2, 83-104 (2021)

10. Solar power a relief to rural health facilities. https:// tanzania.usembassy.gov/pss_02272012.html (accessed April $11,2017)$

11. Tanzania completed - innovation: Africa. https://www. innoafrica.org/tanzania-completed.html (accessed April 11, 2020)

12. Solar electric light fund powers rural clinics in Rwanda. http:// www.self.org/pr_rwanda.pdf (accessed April 12, 2020)

13. United Nations Development Programme, Running health facilities on solar panels in remote rural Zambia, 2015. http://www.undp.org/content/undp/en/home/presscentre/ articles/2015/09/24/running-health-facilities-on-solar-panelsin-remote-rural-zambia0.html (accessed April 6, 2020)

14. World Bank, Solar resource mapping in Zambia: solar modeling report. Washington, D.C.: World Bank Group, 2014. http://documents.worldbank.org/curated/en/2592314679862 45030/Solar-resource-mapping-in-Zambia-solar-modeling-report (accessed April 12, 2020)
15. I. Mbamali, D. Abdulsalam, M. Mamman, Y.M. Saleh, An assessment of solar radiation patterns for sustainable implementation of solar home systems in Nigeria, J. Contemp. Res. 2, 6 (2012)

16. SOLARGIS. GIS data and maps. http://solargis.com/ products/maps-and-gisdata/ (accessed April 7, 2020)

17. O. Tosin, Karshi-Apo road: waiting for light at the end of tunnel, 2012. http://www.dailytrust.com.ng/sunday/index. $\mathrm{php} /$ news /9189-karshi-apo-road-waiting-for-light-at-the-endof-tunnel (accessed September 16, 2020)

18. V.A. Ani, Solar energy system - a life building block for Primary Health Care (PHC) in Nigeria(Grant Proposal), Master of Public Health Dissertation, The Joseph H. and Belle R. Braun, Hebrew University-Hadassah School of Public Health and Community Medicine Jerusalem, Israel, 2017

19. Nigerian Population Commission (NPC), 2006 Census, Abuja Nigeria: Federal Republic of Nigeria official Gazette 2, B1-B42 (2009)

20. Federal Republic of Nigeria, Population Census: National Bureau of Statistics, National Population Commission of Nigeria (2006)

21. Simon Rolland and Guido Glania, Hybrid mini-grids for rural electrification: lessons learned. Alliance for Rural Electrification (ARE). Renewable Energy House, Rue d'Arlon 63-65, 1040 Brussels, Belgium (2011)

22. A. Franco, M. Shaker, D. Kalubi, S. Hostettler, A review of sustainable energy access and technologies for healthcare facilities in the Global South, Sustain. Energy Technol. Assess. 22, 92-105 (2017)

23. S. Khosla, S.K. Singh, Energy efficient buildings, Int. J. Civ. Eng. Res. 5, 361-366 (2014)

Cite this article as: Vincent Anayochukwu Ani, Powering primary healthcare centres with clean energy sources, Renew. Energy Environ. Sustain. 6, 7 (2021) 


\section{Appendix}

Questionnaire on Service Availability Assessment for Energy Module in Health Facility

Basic information

Facility Name:

Street Address:

Select ONLY those apply by ticking $(\boldsymbol{V})$ inside the box

What type of facility is this?

Primary Health Clinic (basic health clinic) $\square$ Primary Healthcare Centre

Health Post $\square$ Maternity $\square$ General Hospital $\square$ Cottage Hospital $\square$

Comprehensive Health Centre $\square$ Ward Model PHC Centre $\square$

Others (specify)

Is this facility open $\overline{24} \overline{\mathrm{h}}$ a day, $\overline{7} \overline{\text { days }}-\overline{\mathrm{a}}$ week?

Yes $\square$ No $\square$

If no, for how long does it open? Specify

\section{Section A: Power supply}

1. What type(s) of power sources are available at this facility? Select ALL that apply and circle
2. Is the power source connected and functional? Respond only for those selected in question 1.

\begin{tabular}{|l|l|l|l|}
\hline None/no power source & 01 & Not applicable & Not applicable \\
\hline Generator & 02 & Yes \\
\hline Grid connection/power/PHCN/NEPA & 03 & Yes & No \\
\hline Other: Please specify:_-_-_-_-_-_-_-_- & 04 & Yes \\
\hline
\end{tabular}

3. How many days in the last month was the facility without electricity/power from any source? Select ONLY one

\begin{tabular}{|c|c|c|c|}
\hline We had power everyday last month & 01 & 16-30 days & 04 \\
\hline 1-5 days & 02 & \multirow{2}{*}{ More than 30 days } & \multirow{2}{*}{05} \\
\hline $6-15$ days & 03 & & \\
\hline
\end{tabular}

4. During the past 7 days, was electricity available at all times (when it was needed) from the main or any backup source when the facility was open for (regular or emergency) services?

\begin{tabular}{|l|l|l|l}
\hline Always available (no interruptions) & 01 & $\begin{array}{l}\text { Sometimes available } \\
\text { (frequent or prolonged interruptions } \\
\text { of more than 2h per day) }\end{array}$ \\
\hline Often available (some interruptions of less than $2 \mathrm{~h}$ per day) & 02 & $\begin{array}{l}\text { 03 } \\
\text { y }\end{array}$
\end{tabular}

5. If connected to the grid, on an average day, how many times does the facility face electricity supply interruptions from the grid?

\begin{tabular}{|l|l|l|l}
\hline No interruptions & 01 & \multirow{2}{*}{ More than 3 interruptions per day } \\
\cline { 1 - 2 } $1-3$ interruptions per day & 02 & \multirow{2}{*}{03} \\
\hline
\end{tabular}

6. If primarily using on-site generation (diesel genset), on an average day, how many times does the facility face electricity supply interruptions?

\begin{tabular}{|l|l|l|l}
\hline No interruptions & 01 & \multirow{2}{*}{ More than 3 interruptions per day } \\
\cline { 1 - 2 } $1-3$ interruptions per day & 02 & \multirow{2}{*}{03}
\end{tabular}

7. On an average day, what is the total duration of all supply interruptions taken together?

\begin{tabular}{|c|c|c|c|}
\hline No interruptions & 01 & $61 \mathrm{~min}$ to $4 \mathrm{~h}$ & 04 \\
\hline Less than $30 \mathrm{~min}$ & 02 & $5-8 \mathrm{~h}$ & 05 \\
\hline $31-60 \mathrm{~min}$ & 03 & More than $8 \mathrm{~h}$ & 06 \\
\hline \multicolumn{4}{|c|}{ 8. When are supply interruptions most common? } \\
\hline Daytime (before dark) & 01 & Overnight (midnight to $8 \mathrm{am}$ ) & 03 \\
\hline Evening (after dark to midnight) & 02 & & \\
\hline \multicolumn{4}{|c|}{ 9. On average, for how many hours in a $24-h$ /day can you avail electricity, should you need to use it? } \\
\hline $4 \mathrm{~h}$ or less & 01 & $17-23 \mathrm{~h}$ & 04 \\
\hline $5-8 \mathrm{~h}$ & 02 & \multirow{2}{*}{$24 \mathrm{~h}$} & \multirow{2}{*}{05} \\
\hline $9-16 \mathrm{~h}$ & 03 & & \\
\hline
\end{tabular}




\begin{tabular}{|c|c|c|c|}
\hline Never open after $6 \mathrm{pm}$ & 01 & Until midnight & 04 \\
\hline Until 8 pm & 02 & \multirow{2}{*}{ All night long } & \multirow{2}{*}{05} \\
\hline Until $10 \mathrm{pm}$ & 03 & & \\
\hline \multicolumn{4}{|c|}{ 11. On average, for how many hours during the evening (after $6 \mathrm{pm}$ ) and night is electricity available at the facility? } \\
\hline Less than $1 \mathrm{~h}$ & 01 & $5-8 \mathrm{~h}$ & 04 \\
\hline $1-2 \mathrm{~h}$ & 02 & \multirow{2}{*}{$8-14 \mathrm{~h}$} & \multirow{2}{*}{05} \\
\hline $3-4 \mathrm{~h}$ & 03 & & \\
\hline
\end{tabular}

12. If you use electricity from the grid, over the last two months, did you have sufficient budgetary allocation (funds available) for paying your electricity bills?

\begin{tabular}{|l|l|l|l}
\hline Yes & 01 & No \\
\hline
\end{tabular}

13. If you use electricity from the grid, who pays the electricity bill for the health clinic?

\begin{tabular}{|l|l|l|l}
\hline Ministry of Health $(\mathrm{MOH})$ & 01 & Donor \\
\hline Combined funds from donor, health facility, ministry of Health & 02 & All electricity is metered and billed to patients & 05 \\
\hline Health facility & 03 & Some electricity is billed to patients \\
\hline
\end{tabular}

14. What is the facility's annual budget for electricity, fuel and maintenance?

\begin{tabular}{|c|c|c|c|}
\hline No budget & 01 & More than 500000 & 04 \\
\hline Between $\$ 50000$ and $\$ 100000$ & 02 & \multirow{2}{*}{ Other (specify) } & \multirow{2}{*}{05} \\
\hline Between $¥ 150000$ and $¥ 500000$ & 03 & & \\
\hline
\end{tabular}

15. Over the last 2 months, did you have sufficient budgetary allocation (funds available) for fuel for the stand-alone generator to operate at all times when it was needed?

\begin{tabular}{|l|l|l|l|}
\hline Yes & 01 & No \\
\hline 16. Who pays for the generator fuel? & 01 & Private purchases by patients or staff \\
\hline Ministry of Health (MOH) & 02 & $\begin{array}{l}\text { Combined funds from donor, health facility, } \\
\text { ministry of Health }\end{array}$ \\
\hline Combination of private purchases and other sources & 05 & Donor \\
\hline Health facility & 03 & 06 \\
\hline
\end{tabular}

17. Over the last two months, did you have sufficient budgetary allocation (funds available) for maintenance of electricity supply equipment?

\begin{tabular}{|l|l|l|l|}
\hline Yes & 01 & No \\
\hline
\end{tabular}

18. If the health facility uses a generator, how long did it take to fix the last time it broke?

Select ONLY one.

\begin{tabular}{|l|l|l|l|}
\hline Never broken & 01 & Broke, fixed within a month \\
\hline Broke, fixed within a day & 02 & More than one month \\
\hline Broke, fixed within a week & 03 & $\begin{array}{l}\text { Not yet fixed: } \\
\text { please specify how long ago it broke }\end{array}$ & $\frac{\text { down (IN MONTHS) }}{-------------~}$ \\
\hline
\end{tabular}

19. Does your primary source of lighting (including kerosene lamps or candles) or electricity causes any pollution of air in the local area in or around the health clinic, through production of fumes or gases that potentially harm the health of the patients or the health workers?

\begin{tabular}{|l|l|l|l}
\hline Yes & 01 & No \\
\hline
\end{tabular}

20. Does your primary source of electricity causes any significant noise pollution in the local area in or around the health clinic that potentially harms the health of the patients or the health workers? 


\section{Section B: Equipment}

21. Do you have this equipment at this health facility? Select all that apply and tick $(\boldsymbol{V})$

\begin{tabular}{|c|c|c|c|c|c|}
\hline CLINICAL MI & Tick $(\boldsymbol{})$ & Total no. of device & Yes & No & $\begin{array}{l}\text { If yes, how long does/should it be } \\
\text { in use per day? specify }\end{array}$ \\
\hline \multicolumn{6}{|l|}{ Micro-nebulizer } \\
\hline \multicolumn{6}{|c|}{ Oxygen concentrator } \\
\hline \multicolumn{6}{|c|}{ Vaccine/lab refrigerator (specify size in L:) } \\
\hline \multicolumn{6}{|c|}{ Suction apparatus } \\
\hline \multicolumn{6}{|c|}{ Vacuum aspirator or D\&C kit } \\
\hline \multicolumn{6}{|l|}{ Incubator } \\
\hline \multicolumn{6}{|l|}{ X-ray machine } \\
\hline \multicolumn{6}{|c|}{ Anaesthesia machine } \\
\hline \multicolumn{6}{|l|}{ CT scanner } \\
\hline \multicolumn{6}{|c|}{ Blood chemistry analyzer } \\
\hline \multicolumn{6}{|l|}{ Centrifuge } \\
\hline \multicolumn{6}{|l|}{ CD4 counter } \\
\hline \multicolumn{6}{|l|}{ Microscope } \\
\hline \multicolumn{6}{|c|}{ Hematology analyzer } \\
\hline \multicolumn{6}{|c|}{ ELISA equipment } \\
\hline \multicolumn{6}{|l|}{ ECG } \\
\hline \multicolumn{6}{|c|}{ Ultrasound equipment } \\
\hline \multicolumn{6}{|c|}{ CLINICAL APPLIANCES } \\
\hline \multicolumn{6}{|c|}{ Electric equipment sterilization autoclave } \\
\hline \multicolumn{6}{|c|}{ General purpose refrigerator (size in litres:) } \\
\hline \multicolumn{6}{|c|}{ Non-electric equipment sterilization autoclave } \\
\hline \multicolumn{6}{|c|}{ INFRASTRUCTURE } \\
\hline \multicolumn{6}{|l|}{ Computer } \\
\hline \multicolumn{6}{|c|}{ Air conditioner unit } \\
\hline \multicolumn{6}{|c|}{ Space heater unit } \\
\hline \multicolumn{6}{|l|}{ Fan } \\
\hline \multicolumn{6}{|l|}{ Radio } \\
\hline \multicolumn{6}{|l|}{ Printer } \\
\hline \multicolumn{6}{|c|}{ Electric water pump } \\
\hline LIGHTING & & & & & \\
\hline Number of roo & & & & & \\
\hline Incandescent li & & & & & \\
\hline Security lights & & & & & \\
\hline
\end{tabular}

22. If available, is it currently functional? Respond only for those that are available at the facility (those selected in 21 ) 


\section{Section C: Staff}

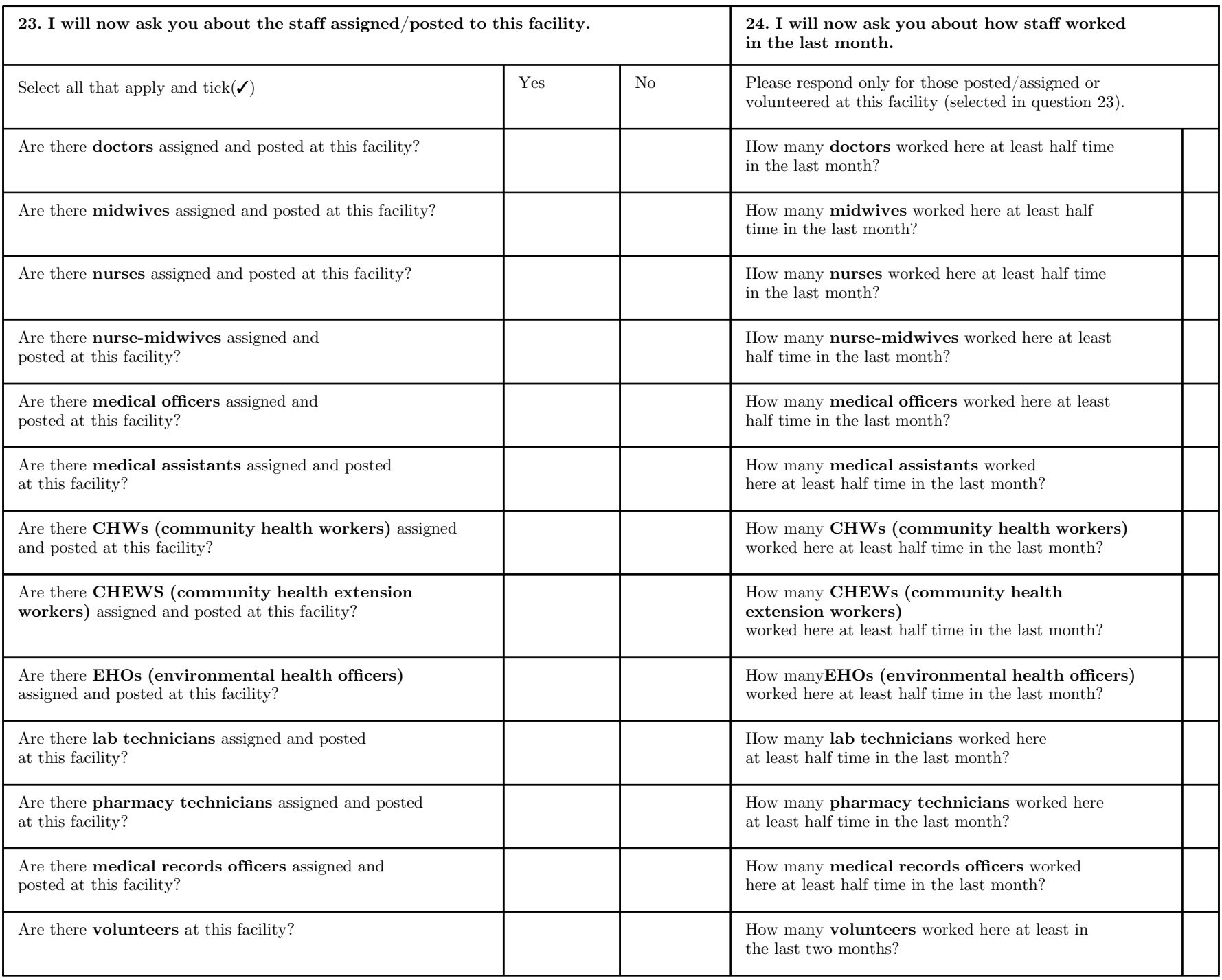




\section{Section D: Services}

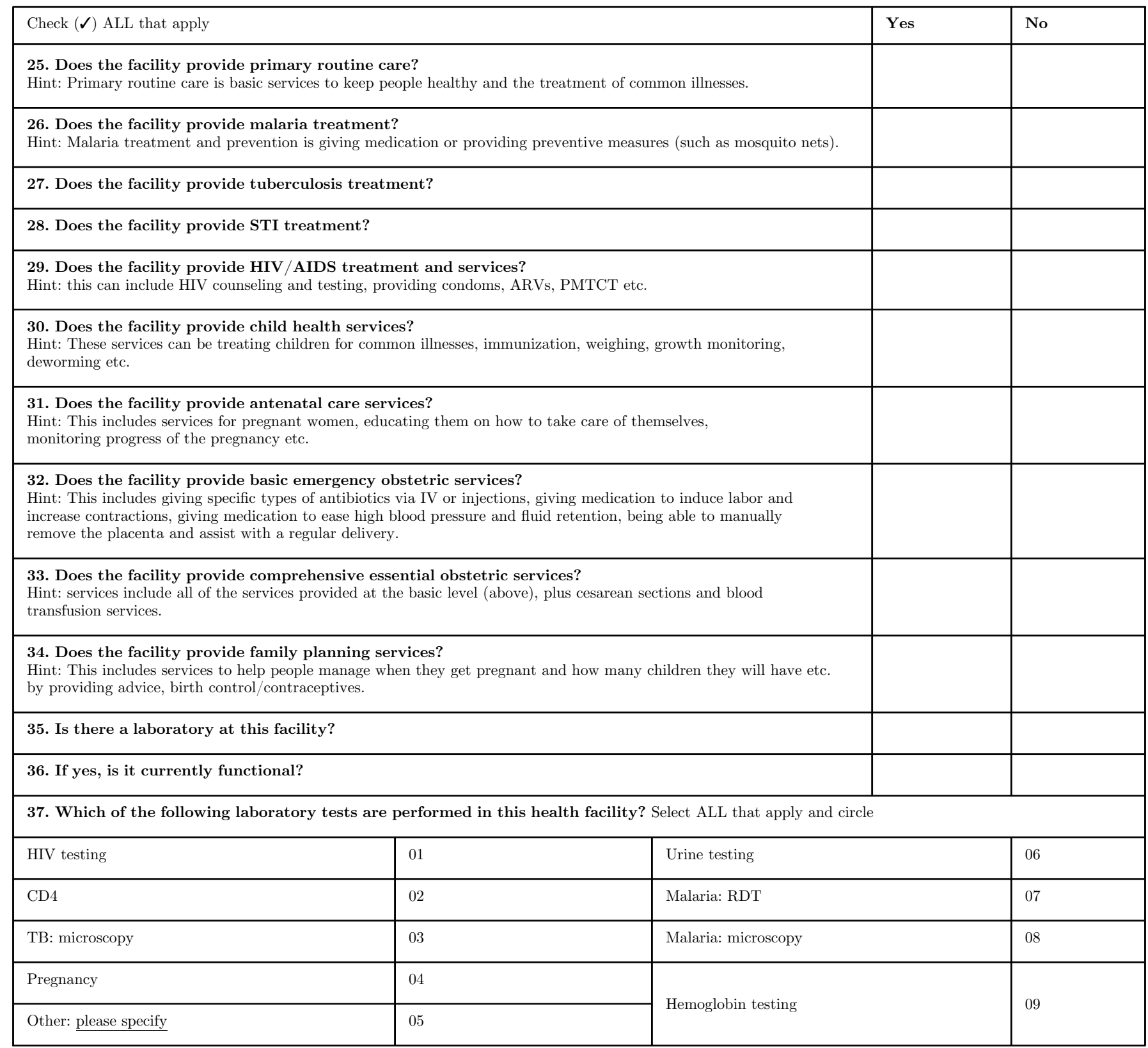


Please add any further comments or suggestions that you may wish to make about the energy issues at the health facility below:

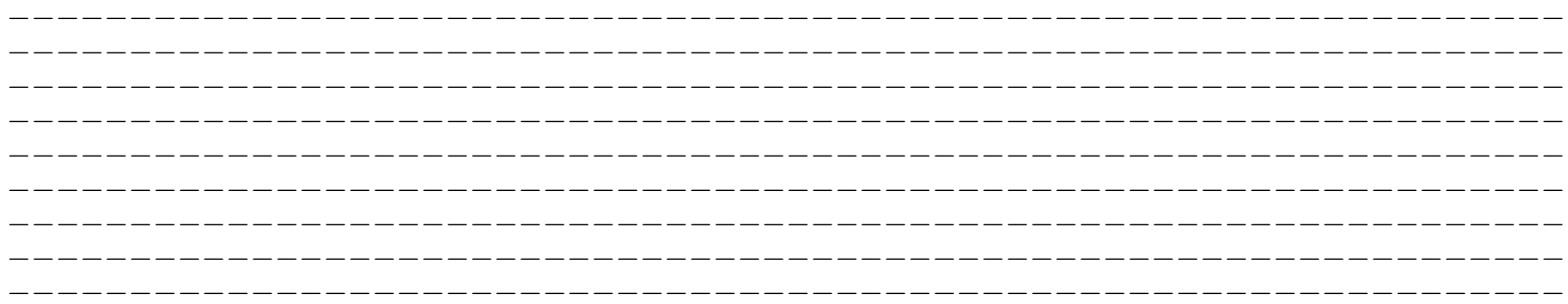

